\title{
Analyses of temporal diversity patterns in a stricto sensu Cerrado fragment
}

\author{
Análisis de patrones de diversidad temporal en un fragmento del Cerrado stricto sensu
}

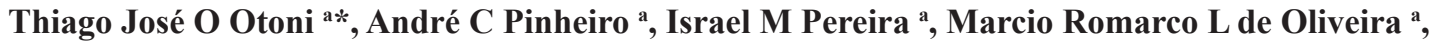 \\ Evandro Luiz M Machado a, Silvia da Luz L Mota ${ }^{\text {b, }}$ Milton Serpa de M Junior ${ }^{\text {b }}$ \\ *Corresponding author: ${ }^{a}$ Universidade Federal dos Vales do Jequitinhonha e Mucuri - UFVJM, Campus JK, \\ Departamento de Engenharia Florestal, Diamantina, MG, Brasil, Rodovia MGT 367 - Km 583, n 5000, \\ Alto da Jacuba CEP 39100-000, tel.: +55 (38) 3532-1248, tj.otoni@gmail.com \\ ${ }^{\mathrm{b}}$ Universidade de Brasília - UnB, Campus Universitário Darcy Ribeiro, Departamento de Engenharia Florestal, \\ Brasília DF, Brasil.
}

\begin{abstract}
SUMMARY
We performed a forest inventory in a fragment of stricto sensu Cerrado to evaluate alpha and beta temporal diversity among adult and natural regeneration (NR) strata. Fifteen plots of $1,000 \mathrm{~m}^{2}(20 \times 50 \mathrm{~m})$ were set to sample the adult stratum, and each plot divided in sub-plots of $100 \mathrm{~m}^{2}(2 \times 50 \mathrm{~m})$ to sample NR. We registered the qualitative (species) and quantitative (height and diameter) floristic composition. Natural Regeneration stratum was divided into three diameter classes (I, II and III). Moreover, species collected on nonoriented paths were registered. We estimated alpha diversity through Shannon index (H'), Pielou index (J') and “one-step" jackknife estimator. Sørensen (Sø-qualitative) and Czekanowski (SC - quantitative) indexes were used to evaluate beta diversity. In total, 101 species distributed in 71 genera and 36 families were recorded. For the adult and NR strata, H' values were 3.06 and 3.14 nats per individual, and J' 0.75 and 0.71 , respectively. Both strata had qualitative similarity. Natural regeneration showed no similarity with adult stratum by Czekanowski index, although this distance tends to decline with the progressive size of each class. The temporal beta diversity is low between these strata; and there is a trend of increasing similarity with the maturity of NR.
\end{abstract}

Key words: savannah, floristic similarity, vegetation, Curvelo-MG.

\section{RESUMEN}

Un inventario forestal se realizó en un fragmento de Cerrado stricto sensu donde se evaluaron los índices de diversidad temporal alfa y beta entre los estratos adulto y regeneración natural $(\mathrm{RN})$. Se establecieron quince parcelas de $1.000 \mathrm{~m}^{2}(20 \times 50 \mathrm{~m})$ para el estrato adulto de la muestra, y para el estrato de RN se establecieron sub-parcelas de $100 \mathrm{~m}^{2}(2 \times 50 \mathrm{~m})$. Se registraron parámetros cualitativos (especies) y cuantitativos (altura y diámetro) para evaluar la composición florística. El estrato de RN se dividió en tres clases diamétricas (I, II y III). Por otra parte, se realizó el registro de las especies encontradas en trayectos no-orientados. La diversidad alfa se estimó por Índice de Shannon (H'), Pielou (J') y el estimador jackknife “un solo paso”. Sin embargo, en los parámetros cualitativos se uso índice de Sørensen (SO) y para los parámetros cuantitativos fue usado índice de Czekanowski (SC), evaluando la diversidad beta. En total, se registraron 101 especies distribuidas en 71 géneros y 36 familias. Para los estratos adulto y RN, el valor H' fue de 3,06 y 3,14 nats per individual, y para J' fue de 0,75 y 0,71, respectivamente. Ambos estratos presentaron similitud cualitativa. La RN no mostró similitud con el estrato adulto por índice Czekanowski, pero la diferencia tiende a disminuir con el tamaño progresivo de las clases diamétricas. La diversidad beta temporal es baja entre los estratos; y existe una tendencia a una mayor similitud entre los estratos a mayor madurez de la RN.

Palabras clave: sabana, similitud florística, vegetación, Curvelo-MG.

\section{INTRODUCTION}

Cerrado lato sensu has a vegetation gradient with two extreme physiognomies (open areas and dense forest); however, in the core area, a stricto sensu type predominates and covers a large area of this phytophysionomy. In recent decades, Mendonça et al. (2008) have described Cerrado vegetation as rich in species; nevertheless due to current critical deforestations, Mittermeier et al. (2005) pointed Cerrado as a priority area for global conservation; the high degree of endemism and biodiversity threatened by chaotic occupation.

This ecosystem covers originally more than $40 \%$ of Brazilian territory, and comprises more than $30 \%$ of the national biota. It constitutes one of the largest sets of ecosystems in this country, besides being the richest tropical savanna in species worldwide (Ribeiro and Walter 2008). 
Taxonomic Diversity is one of the most used parameters in ecology to characterize ecosystems. Cerrado diversity patterns were described by Felfili and Silva-Júnior (2001), Ratter et al. (2003), Felfili et al. (2004), Bridgewater et al. (2004) and Felfili and Silva-Júnior (2005), among others, as proving the high alpha and beta diversity of this vegetation. This way, the scientific community is performing considerable efforts and a growing number of investigative studies in Cerrado vegetation areas, mainly in stricto sensu type. Moreover, they draw attention to the unlimited demand for information on vegetation structural changes throughout timeline: how such plants behave over the successional axis, besides the lack of functional information on biome's species.

Studies with temporal analyses have resulted in important data on vegetation dynamics; such as community behavior towards stability, based on demographics, species composition and other factors (Libano and Felfili 2006). Natural regeneration studies reflect growth conditions that produce floristic and structural variations within plant community over time, which can be measured directly by vegetation dynamics and indirectly through a temporal analysis of beta diversity between adult and NR strata, as performed by Medeiros et al. (2007). Studies of this nature provide important information on the functioning of the community and its changes in response to eventual disorders.

Although there is difficulty to provide replacement standards of species in a community, Guariguata and Von Ostertag (2001) reported that there is a sequence of events and processes that occur during the secondary succession, which does not depend on the composition of species. This sequence starts with initial colonization, increase of biomass and finally a return of the composition of species. According to Guariguata et al. (1997), to understand the secondary succession and assess how disorders may modify the structure and wealth of forests, studies involving the dynamics of natural regeneration are required. Thus, comparisons between the structural patterns of adult class with the classes of regeneration which already have overcome the selective pressure of the environment may provide important information on the potentially regenerative capacity of the community.

Aiming at generating information to support projects of management, conservation and recovery of natural areas, this study is intended for evaluating alpha and temporal beta diversities in a stricto sensu Cerrado area by comparing adult and natural regeneration strata. We started by the hypothesis of alpha diversity being higher and natural regeneration resembling adult stratum, i.e., beta diversity being low.

\section{METHODS}

The study was carried out in a Cerrado fragment $\left(18.84^{\circ} \mathrm{S}\right.$ and $44.39^{\circ} \mathrm{W}$, with an average altitude of 715 m). It is located in Curvelo City, State of Minas Gerais, Brazil. The area lies within São Francisco River watershed (figure 1). The fragment has approximately 54.0 ha.

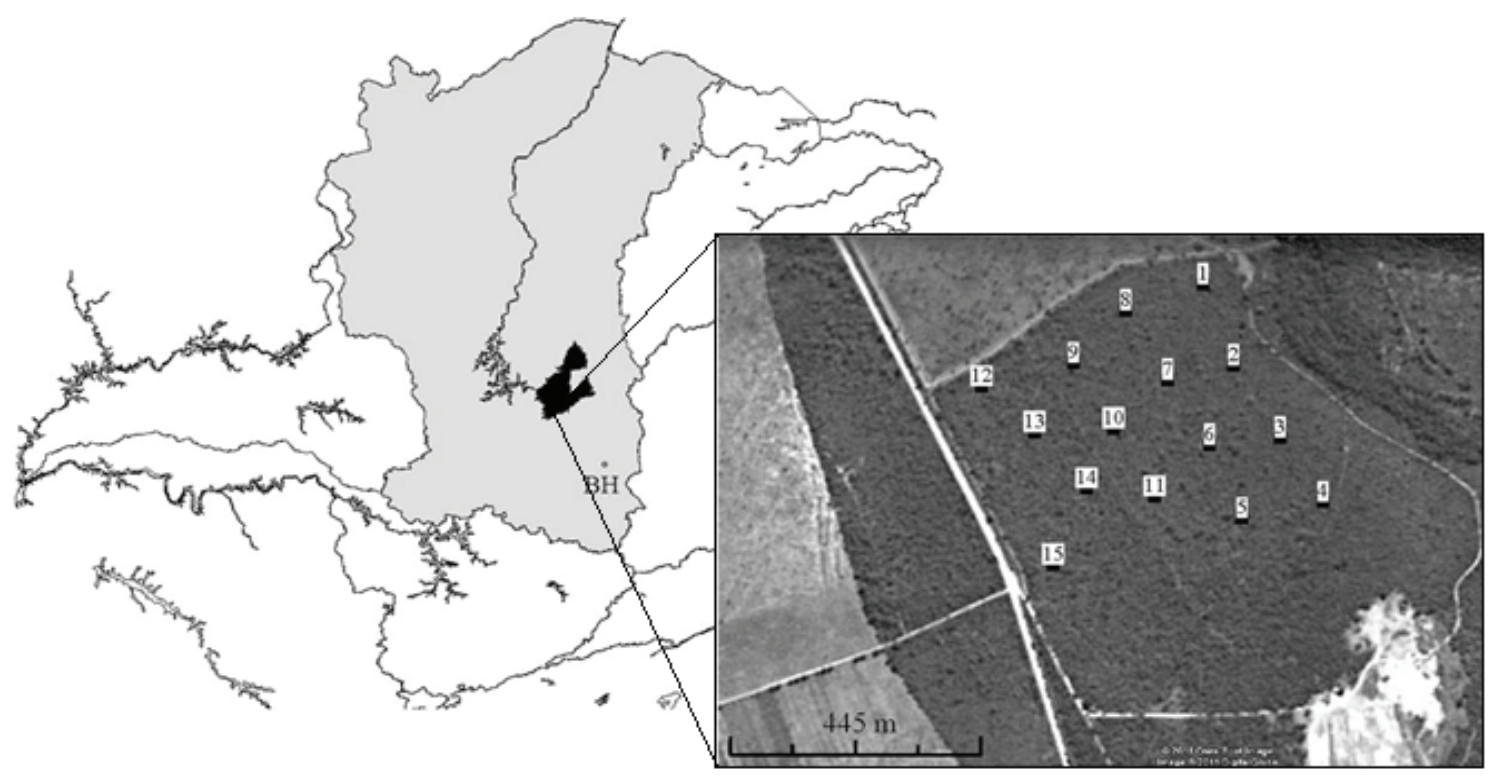

Figure 1. State of Minas Gerais, in Brazil, highlighting São Francisco Watershed (in gray) and the city of Curvelo (in black); the illustrative scheme of plot allocations within a stricto sensu Cerrado fragment, which is the Experimental Farm of Campus do Moura in Curvelo - MG, Brazil.

Estado de Minas Gerais, Brasil, destacando la Cuenca del Río São Francisco (en gris) y la ciudad de Curvelo (en negro); ampliando el diseño de la distribución de las parcelas dentro de un fragmento de Cerrado stricto sensu, en la Finca Experimental del Campus que Moura en Curvelo, MG, Brasil. 
The area has an $A w$ climate type (tropical with dry winters) as Köppen's classification, which is identified as tropical savanna climate, with average temperatures around $28^{\circ} \mathrm{C}$ and rainfall around $1,200 \mathrm{~mm}_{\text {year }}{ }^{-1}$, concentrated in the summer (Strahler and Strahler 2002).

The plant community under study was identified as proposed by Ribeiro and Walter (2008) as a stricto sen$s u$ Cerrado on a dystrophic substrate and acidic Latosol (Oxisol). There is a predominance of herbaceous plants composed mainly by natural and exotic grasses, mostly at the borders.

Within phanerophytes, two strata were sampled (Felfili et al. 2005). One composed by adult plants - with diameter at $30 \mathrm{~cm}$ height $\geq 5.0 \mathrm{~cm}$; and natural regeneration - with diameter $<5.0 \mathrm{~cm}$ and plant height $\geq 10 \mathrm{~cm}$. Forest inventory was performed using permanent area plots (Mue1ler-Dombois and Ellenberg 1974), carried between July 2009 and January 2010 for the adult stratum, and in July 2010 for natural regeneration. Two plot sizes were performed and added to samplings made by a non-oriented path method (Filgueiras et al. 1994).

Shape and size of the plots used in the adult stratum were based on the methodology adopted by Felfili and Silva-Júnior (2001), with an area of 1,000 $\mathrm{m}^{2}$ and dimensions of $20 \times 50 \mathrm{~m}$. For individuals of natural regeneration, subplots of $100 \mathrm{~m}^{2}(2 \times 50 \mathrm{~m})$ were used within adult plots. The sampling units were systematically installed at distances of $\mathrm{k}=100 \mathrm{~m}$ between plots and lines. The stricto sensu Cerrado was included in the study, totaling 30 sample units (15 plots and 15 sub-plots), which can be seen in figure 1 .

All shrubby-arboreal living individuals, in which the inclusion criteria in the boundaries of plot was met, were identified and received numbered boards. Plants with basal branches (tillers) were recorded as unique and included when the equivalent diameter or height (natural regeneration) met established criteria.

After inventory, natural regeneration individuals were classified into three size classes according to the methodology adapted from Finol (1971): Class I - (BD between 0.028 and $2.0 \mathrm{~cm}$ ); Class II (BD between 2.0 and $4.0 \mathrm{~cm}$ ); and Class III (BD between 4.0 and $5.0 \mathrm{~cm}$ ). Diameter was used as criterion for this classification due to measure easiness and accuracy at field for Cerrado environment; reducing the risk of specimens migration to lower classes due to diverse natural eventualities that are most reflective in plant height. All underlying analyzes were performed for comparisons between adult and natural regeneration strata and to compare the natural regeneration diameter classes (I, II and III).

Alpha diversity was estimated by the following parameters: species richness and abundance distribution by Shannon diversity index ( $\mathrm{H}^{\prime}$ ) and Pielou evenness (J') (Legendre and Legendre 1998). "One-step" jackknife estimator (Palmer 1990, 1991) evaluated total richness of the samples. This author concluded that "one-step" jackknife projection is less biased to estimate the real species richness.
Similarity tests were performed among the sampled strata (adult and natural regeneration) to check changes in floristic pattern arising from beta diversity in a time axis. Sørensen ( $\mathrm{S}_{\varnothing}-$ qualitative) and Czekanowski $\left(\mathrm{S}_{\mathrm{C}}-\right.$ quantitative) were performed (Legendre and Legendre 1998). These indexes vary between zero and one, and for this study, pairwise comparisons whose values exceeded 0.5 were regarded as similar in both indexes (Kent and Coker 1992). For quantitative index, plot density values of adults and natural regeneration were given in terms of area.

A species list was assembled, ordered by family, pointing the stratum (adult or natural regeneration) in which it was sampled. Species found along the non-oriented path were also included in the list. Scientific name spelling, authors and botanic family, followed the database provided by the Missouri Botanical Garden (2014) and APG III (2009).

\section{RESULTS}

In this study, a number of 6,602 individuals were recorded, between adults $(3,091)$ and natural regeneration $(3,510)$, representing an estimate of 25,461 plants per hectare (2,061 adult 23,400 natural regeneration). These individuals were divided into 35 families, 66 genera, 83 species and 29 unidentified specimens that were morphologically grouped into 12 groups; resulting in a richness of 92 taxa for the plot method. Non-oriented path added up nine species to the richness value, hence in a total of 101 shrubby-arboreal taxa. These taxonomic values range between strata as detailed in table 1 .

Jackknife estimator indicated a richness value superior to plot samples, supporting results found in the non-oriented path. Jackknife richness nonparametric projections (one-step) were 63.67 and 107.27 for adult and natural regeneration, respectively. Natural regeneration inflated values are due to several species with low abundance within the samples $(<10$ individuals). Table 2 details shrub and tree sampled flora.

Nine species are unique to the adult stratum when compared with the RN classes: Jacaranda brasiliana, Curatella americana, Dalbergia miscolobium, Enterolobium gummiferum, Eriotheca pubescens, Rudgea viburnoides, Styrax ferrugineus, Salvertia convallariodora and Vochysia rufa. The adult stratum had a higher number of unique species compared with the natural regeneration class III.

Sapindaceae family, represented by a single species (Magonia pubescens), had dominance regarding number of individuals (around $23 \%$ ), surpassing the Fabaceae family $(14 \%)$ in more than 2,000 specimens per hectare, which was ranked right below by density between adult and natural regeneration. The other families with high density values were Celastraceae (10\%), Erythroxylaceae (10\%), Vochysiaceae (8\%) and Apocynaceae (6\%).

Regarding the most abundant species for adult stratum, Magonia pubescens (27.1\%), Qualea parviflora $(9.12 \%)$, 
Table 1. Richness values found in the plots plus species added from non-oriented paths, broken down by stratum in which species were registered, within a stricto sensu Cerrado fragment in the Experimental Farm of the Campus do Moura, Curvelo - MG, Brazil. Wherein: I, II and III are size classes of the natural regeneration (NR) stratum.

Valores de riqueza que se encontraron en las parcelas, más especies añadidas durante los trayectos, desglosados por estrato en el cual se registraron las especies, dentro de un fragmento de Cerrado stricto sensu en la Granja Experimental del Campus do Moura, Curvelo, MG, Brasil. Donde: I, II y III son clase diamétricas del estrato de regeneración natural (NR).

\begin{tabular}{|c|c|c|c|c|c|c|c|c|c|c|}
\hline \multirow{2}{*}{ Taxa } & \multicolumn{6}{|c|}{ Plots } & \multicolumn{3}{|c|}{ Path } & \multirow{2}{*}{ Tota } \\
\hline & Adult & NR I & NR II & NR III & NR & Sub-total & Adult & NR & Sub-total & \\
\hline Family & 30 & $33^{-}$ & $30^{-}$ & 22 & 34 & $35^{-}$ & 5 & 7 & 8 & $36^{-}$ \\
\hline Genus & 51 & $51^{-}$ & $42^{-}$ & 30 & $57^{-}$ & 66 & 5 & 8 & 9 & $71^{-}$ \\
\hline Species & 59 & 76 & 51 & 36 & 83 & 92 & 5 & 8 & 9 & 101 \\
\hline
\end{tabular}

“ - " underestimated values due to non-identification of 12 morphospecies.

Table 2. Floristic list of shrub and tree species sampled in a stricto sensu Cerrado fragment at Experimental Farm of Campus do Moura/ UFVJM, in Curvelo - MG, Brazil. For each stratum (adult and natural regeneration - NR) and NR diameter classes (I, II and III).

Lista de especies arbustivas y arbóreas muestreadas en un fragmento de Cerrado stricto sensu en la granja experimental del Campus do Moura/UFVJM, en Curvelo, MG, Brasil. Para cada estrato (adulto y regeneración natural - RN) por clases de diámetro RN (I, II y III).

\begin{tabular}{|c|c|c|c|c|c|c|}
\hline \multirow{2}{*}{ Family } & \multirow{2}{*}{ Species } & \multicolumn{5}{|c|}{ Number of individuals } \\
\hline & & Adult & NR & NR I & NR II & NR III \\
\hline Anacardiaceae & Astronium fraxinifolium Schott ex Spreng.* & 100 & 53 & 33 & 16 & 4 \\
\hline Annonaceae & Annona cornifolia A.St.-Hil. & 0 & 19 & 17 & 2 & 0 \\
\hline Annonaceae & Annona crassiflora Mart.* & 28 & 4 & 4 & 0 & 0 \\
\hline Annonaceae & Annona sylvatica A.St.-Hil. & 0 & 7 & 7 & 0 & 0 \\
\hline Annonaceae & Duguetia forfuracea (A.St.-Hil) Saff* & 0 & 5 & 3 & 2 & 0 \\
\hline Annonaceae & Xylopia aromatica (Lam.) Mart.* & 2 & 1 & 1 & 0 & 0 \\
\hline Apocynaceae & Aspidosperma tomentosum Mart.* & 76 & 235 & 202 & 29 & 4 \\
\hline Apocynaceae & Himatanthus obovatus (Müll.Arg.) Woodson* & 0 & 1 & 1 & 0 & 0 \\
\hline Aquifoliaceae & Ilex affinis Gardner & 0 & 1 & 1 & 0 & 0 \\
\hline Araliaceae & Schefflera macrocarpa (Cham. et Schltdl.) Frodin & 12 & 1 & 1 & 0 & 0 \\
\hline Asteraceae & Baccharis dracunculifolia DC. & 0 & 1 & 1 & 0 & 0 \\
\hline Asteraceae & Piptocarpha rotundifolia (Less.) Baker* & 61 & 60 & 35 & 18 & 7 \\
\hline Bignoniaceae & Cybistax antisyphilitica (Mart.) Mart.* & & & $\times$ & & \\
\hline Bignoniaceae & Handroanthus ochraceus (Cham.) Mattos* & 21 & 15 & 15 & 0 & 0 \\
\hline Bignoniaceae & Jacaranda brasiliana (Lam.) Pers. & 1 & 0 & 0 & 0 & 0 \\
\hline Bignoniaceae & Tabebuia aurea (Manso) Benth. et Hook.f. ex S.Moore* & 47 & 1 & 0 & 1 & 0 \\
\hline Bignoniaceae & Zeyheria montana Mart.* & 1 & 2 & 2 & 0 & 0 \\
\hline Caryocaraceae & Caryocar brasiliense Cambess.* & 34 & 32 & 23 & 6 & 3 \\
\hline Celastraceae & Peritassa campestris (Cambess.) A.C. Sm. & 0 & 362 & 355 & 6 & 1 \\
\hline Celastraceae & Plenckia populnea Reissek* & 47 & 22 & 11 & 9 & 2 \\
\hline Chrysobalanaceae & Couepia grandiflora (Mart. et Zucc.) Benth. ex Hook.f.* & 0 & 3 & 1 & 2 & 0 \\
\hline Clusiaceae & Kielmeyera coriacea Mart. et Zucc.* & 222 & 44 & 27 & 14 & 3 \\
\hline Combretaceae & Terminalia argentea (Cambess.) Mart.* & 37 & 56 & 49 & 5 & 2 \\
\hline
\end{tabular}


Table 2 Continued

\begin{tabular}{|c|c|c|c|c|c|c|}
\hline Connaraceae & Connarus suberosus Planch.* & 5 & 3 & 2 & 0 & 1 \\
\hline Connaraceae & Rourea induta Planch. & 0 & 14 & 5 & 8 & 1 \\
\hline Dilleniaceae & Curatella americana L.* & 4 & 0 & 0 & 0 & 0 \\
\hline Dilleniaceae & Davilla elliptica A.St.-Hil.* & 0 & 12 & 9 & 3 & 0 \\
\hline Ebenaceae & Diospyros burchellii Hiern.* & 51 & 46 & 30 & 10 & 6 \\
\hline Ebenaceae & Diospyros hispida A.DC.* & & & $\times$ & & \\
\hline Erythroxylaceae & Erythroxylum campestre St. Hil. & 2 & 201 & 161 & 28 & 12 \\
\hline Erythroxylaceae & Erythroxylum daphnites Mart. & 0 & 47 & 47 & 0 & 0 \\
\hline Erythroxylaceae & Erythroxylum deciduum A.St.-Hil.* & 56 & 31 & 30 & 0 & 1 \\
\hline Erythroxylaceae & Erythroxylum suberosum A.St.-Hil.* & 138 & 58 & 42 & 15 & 1 \\
\hline Erythroxylaceae & Erythroxylum tortuosum Mart.* & 10 & 18 & 9 & 9 & 0 \\
\hline Fabaceae & Andira vermifuga (Mart.) Benth.* & 1 & 1 & 0 & 0 & 1 \\
\hline Fabaceae & Bauhinia rufa (Bong.) Steud. & 0 & 230 & 217 & 13 & 0 \\
\hline Fabaceae & Bowdichia virgilioides Kunth* & 36 & 7 & 5 & 2 & 0 \\
\hline Fabaceae & Copaifera langsdorffii Desf.* & & & $x$ & & \\
\hline Fabaceae & Dalbergia miscolobium Benth.* & 5 & 0 & 0 & 0 & 0 \\
\hline Fabaceae & Dimorphandra mollis Benth.* & 15 & 12 & 7 & 4 & 1 \\
\hline Fabaceae & Enterolobium gummiferum (Mart.) J.F.Macbr.* & 4 & 0 & 0 & 0 & 0 \\
\hline Fabaceae & Fabaceae1 & 0 & 5 & 5 & 0 & 0 \\
\hline Fabaceae & Hymenaea stigonocarpa Mart. ex Hayne* & 13 & 4 & 0 & 4 & 0 \\
\hline Fabaceae & Leptolobium dasycarpum Vogel* & 39 & 13 & 5 & 6 & 2 \\
\hline Fabaceae & Machaerium opacum Vogel* & 48 & 68 & 54 & 14 & 0 \\
\hline Fabaceae & Machaerium tomentosum Glaz. & & & $\times$ & & \\
\hline Fabaceae & Plathymenia reticulata Benth.* & 21 & 16 & 13 & 3 & 0 \\
\hline Fabaceae & Senna macranthera (DC. ex Collad.) H.S.Irwin e Barneby & 0 & 3 & 3 & 0 & 0 \\
\hline Fabaceae & Stryphnodendron adstringens (Mart.) Cov.* & 12 & 4 & 0 & 3 & 1 \\
\hline Fabaceae & Tachigali aurea Tul.* & 34 & 14 & 11 & 2 & 1 \\
\hline Fabaceae & Tachigali subvelutina (Benth.) Oliveira-Filho* & 0 & 1 & 1 & 0 & 0 \\
\hline Fabaceae & Vatairea macrocarpa (Benth.) Ducke* & 91 & 111 & 86 & 24 & 1 \\
\hline Lamiaceae & Aegiphila verticillata Vell.* & 1 & 1 & 1 & 0 & 0 \\
\hline Loganiaceae & Antonia ovata Pohl & & & $\times$ & & \\
\hline Loganiaceae & Strychnos pseudoquina A.St.-Hil.* & 9 & 10 & 9 & 1 & 0 \\
\hline Lythraceae & Lafoensia vandelliana Cham. et Schltdl.* & 63 & 34 & 27 & 5 & 2 \\
\hline Malpighiaceae & Byrsonima coccolobifolia Kunth* & 111 & 28 & 11 & 13 & 4 \\
\hline Malpighiaceae & Byrsonima pachyphylla A.Juss.* & 11 & 3 & 1 & 1 & 1 \\
\hline Malpighiaceae & Byrsonima verbascifolia (L.) DC.* & 42 & 9 & 4 & 4 & 1 \\
\hline Malvaceae & Eriotheca pubescens (Mart. et Zucc.) Schott et Endl.* & 8 & 0 & 0 & 0 & 0 \\
\hline Malvaceae & Pseudobombax longiflorum (Mart. et Zucc.) A.Robyns* & 2 & 2 & 0 & 1 & 1 \\
\hline Malvaceae & Pseudobombax tomentosum (Mart. et Zucc.) A.Robyns & & & $\times$ & & \\
\hline Moraceae & Brosimum gaudichaudii Trécul* & 0 & 9 & 7 & 2 & 0 \\
\hline
\end{tabular}


Table 2 Continued

\begin{tabular}{|c|c|c|c|c|c|c|}
\hline Myrsinaceae & Cybianthus sp. & 0 & 2 & 2 & 0 & 0 \\
\hline Myrtaceae & Campomanesia velutina (Cambess.) O.Berg & 0 & 1 & 1 & 0 & 0 \\
\hline Myrtaceae & Eugenia capparidifolia & 0 & 1 & 1 & 0 & 0 \\
\hline Myrtaceae & Eugenia dysenterica DC.* & 6 & 25 & 24 & 0 & 1 \\
\hline Myrtaceae & Myrcia guianensis (Aubl.) DC. & 12 & 39 & 31 & 6 & 2 \\
\hline Myrtaceae & Myrtaceae1 & 0 & 1 & 1 & 0 & 0 \\
\hline Myrtaceae & Psidium myrtoides O.Berg & 0 & 1 & 0 & 1 & 0 \\
\hline Ochnaceae & Ouratea hexasperma (A.St.-Hil.) Baill.* & 57 & 40 & 23 & 14 & 3 \\
\hline Opiliaceae & Agonandra brasiliensis Miers ex Benth. et Hook.* & 4 & 6 & 6 & 0 & 0 \\
\hline Proteaceae & Roupala montana Aubl.* & 14 & 85 & 68 & 15 & 2 \\
\hline Rubiaceae & Guettarda viburnoides Cham. et Schltdl. & & & $x$ & & \\
\hline Rubiaceae & Palicourea rigida Kunth* & 10 & 9 & 1 & 8 & 0 \\
\hline Rubiaceae & Rudgea viburnoides (Cham.) Benth.* & 1 & 0 & 0 & 0 & 0 \\
\hline Rubiaceae & Tocoyena formosa (Cham. et Schltdl.) K.Schum.* & 22 & 24 & 15 & 8 & 1 \\
\hline Salicaceae & Casearia decandra Jacq. & 0 & 1 & 1 & 0 & 0 \\
\hline Salicaceae & Casearia sylvestris $\mathrm{Sw} . *$ & 0 & 233 & 230 & 3 & 0 \\
\hline Sapindaceae & Magonia pubescens A.St.-Hil.* & 835 & 778 & 576 & 142 & 60 \\
\hline Sapotaceae & Pouteria ramiflora (Mart.) Radlk.* & 99 & 27 & 19 & 7 & 1 \\
\hline Sapotaceae & Pouteria torta (Mart.) Radlk.* & 4 & 13 & 7 & 6 & 0 \\
\hline Solanaceae & Solanum lycocarpum A.St.-Hil.* & & & $x$ & & \\
\hline Styracaceae & Styrax camporum Pohl* & & & $x$ & & \\
\hline Styracaceae & Styrax ferrugineus Nees et Mart.* & 17 & 0 & 0 & 0 & 0 \\
\hline Verbenaceae & Aloysia virgata (Ruiz et Pav.) A.Juss. & 22 & 11 & 1 & 5 & 5 \\
\hline Vochysiaceae & Qualea grandiflora Mart.* & 130 & 100 & 85 & 12 & 3 \\
\hline Vochysiaceae & Qualea multiflora Mart.* & 49 & 13 & 9 & 3 & 1 \\
\hline Vochysiaceae & Qualea parviflora Mart.* & 282 & 138 & 109 & 22 & 7 \\
\hline Vochysiaceae & Salvertia convallariodora A.St.-Hil.* & 2 & 0 & 0 & 0 & 0 \\
\hline Vochysiaceae & Vochysia rufa Mart.* & 4 & 0 & 0 & 0 & 0 \\
\hline Unidentified & Unidentified1 & 0 & 1 & 1 & 0 & 0 \\
\hline Unidentified & Unidentified2 & 0 & 2 & 2 & 0 & 0 \\
\hline Unidentified & Unidentifie3 & 0 & 1 & 0 & 1 & 0 \\
\hline Unidentified & Unidentified4 & 0 & 2 & 2 & 0 & 0 \\
\hline Unidentified & Unidentified5 & 0 & 9 & 8 & 1 & 0 \\
\hline Unidentified & Unidentified6 & 0 & 2 & 2 & 0 & 0 \\
\hline Unidentified & Unidentified7 & 0 & 2 & 2 & 0 & 0 \\
\hline Unidentified & Unidentified8 & 0 & 1 & 1 & 0 & 0 \\
\hline Unidentified & Unidentified9 & 0 & 1 & 1 & 0 & 0 \\
\hline Unidentified & Unidentified 10 & 0 & 1 & 1 & 0 & 0 \\
\hline Total & - & 3,091 & 3,510 & 2,821 & 539 & 150 \\
\hline
\end{tabular}

Species marked with * are the most frequent in the central southeastern province (Ratter et al. 2003, Bridgewater et al. 2004) and the species sampled only in the non-oriented path were indicated by $\times$ in column of densities. 
Kielmeyera coriacea (7.18 \%), Erythroxylum suberosum (4.46\%) and Qualea grandiflora (4.21\%) account for more than $50 \%$ total density. In natural regeneration, $\mathrm{Ma}$ gonia pubescens (22.2 \%) is again highlighted, followed by Peritassa campestris (10.31\%), Astronium tomentosum $(6.7 \%)$, Casearia sylvestris (6.64 \%) and Bauhinia rufa $(6.55 \%)$, which together represent more than half of natural regeneration population.

Among the 30 most abundant species in the adult stratum, all were present in natural regeneration. However, nine species were not listed in this stratum (Curatella americana, Enterolobium gummiferum, Rudgea viburnoides, Salvertia convallariodora, Vochysia rufa, Jacaranda brasiliana, Styrax ferrugineus, Eriotheca pubescens and Dalbergia miscolobium). In this list, all species had less than five individuals per hectare, except for Styrax ferrugineus (about 11 individuals ha ${ }^{-1}$ ) and Eriotheca pubescens (about 5 individuals ha ${ }^{-1}$ ).

Adult and natural regeneration strata respectively obtained the values of 3.06 and 3.14 nats per individual for Shannon index (H'), and of 0.75 and 0.71 for Pielou index (J'). These values demonstrate the ecological oligarchy of Magonia pubescens in both strata; moreover, they show a relatively uniform approach among most species.

For I, II and III diameter classes, H' values were respectively $3.04,3.19$ and 2.61 nats per individual; and J' were 0.70 , 0.81 and 0.72 , also in that order. Additionally, it was noted that Class II has higher diversity $\left(>\mathrm{H}^{\prime}\right)$, despite smaller number of species, once this complexity is ensured by more evenness in species abundance distribution (Pielou index).

Adult and natural regeneration similarity was 0.704 by Sørensen qualitative index. In contrast, the quantitative analysis showed dissimilarity, whose Czekanowski index was near zero (table 3 ).

\section{DISCUSSION}

Specifically for stricto sensu Cerrado physiognomy, Felfili et al. (2004) stated that richness rarely exceeds 100 species per hectare by plot method. Studying beta diversi- ty in Central Brazil, these authors found an average of 73 species per hectare. Even, Scolforo et al. (2008), analyzing four areas of stricto sensu Cerrado in Minas Gerais, estimated an average of 70 species per community in Curvelo - MG, using similar data collection methods. This confirms the low alpha diversity of adult stratum in the micro-region.

On the other hand, the natural regeneration richness estimated in this study ( 83 species), in $1,500 \mathrm{~m}^{2}$, was higher than that estimated by Barreira et al. (2002), also in stricto sensu Cerrado within the same watershed (Brasilândia de Minas - MG) and under similar climatic factors. These authors sampled 48 shrubby-arboreal species in $1,800 \mathrm{~m}^{2}$. In addition, Medeiros et al. (2007) observed a lower value in this study of richness of natural regeneration (49 species) in an area of stricto sensu Cerrado in Central Brazil. Even by adapting this study database to the different inclusion criteria of the above-mentioned studies, our values of richness remained higher for natural regeneration areas.

For adult stratum, the richness found in this study, even that estimated by jackknife, can be considered low according to literature (Ratter et al. 2003, Felfili et al. 2004, Scolforo et al. 2008). Nevertheless, natural regeneration had superior values compared with those normally found for the same environment (Barreira et al. 2002, Medeiros et al. 2007).

In regional context, Cerrado areas within Curvelo city (MG) belong to the central southeastern province given by Ratter et al. (2003), as a floristic group of this vegetation, composed by 428 species recorded for more than 70 areas of Cerrado ecosystem. Bridgewater et al. (2004) list 100 species most found in such province, from which 66 are added into the total richness encountered in this study (table 2), corroborating the proposal of Ratter et al. (2003).

Among the observed botanical families, Fabaceae showed the highest richness, with 18 species (16 within the plots and 2 from the path). This result meets literature findings (Barreira et al. 2002, Ratter et al. 2003, Felfili et al. 2004, Medeiros et al. 2007, Mendonça et al. 2008), as expected, since it is the third largest botanical family of

Table 3. Values of qualitative and quantitative floristic similarities between adult and natural regeneration (NR) strata. Detailing of NR by diameter classes I, II, and III.

Valores de similitud florística cualitativa y cuantitativa entre los estratos adulto y regeneración natural (RN). Detallando RN por clases diamétricas I, II, y III.

\begin{tabular}{|c|c|c|c|c|c|c|c|}
\hline \multirow[b]{2}{*}{ Adult } & Adult & NR & \multirow[b]{2}{*}{ Adult } & Adult & NR I & NR II & NR III \\
\hline & 1 & $0.157^{*}$ & & 1 & $0.189^{*}$ & $\underline{0.619^{*}}$ & $\underline{0.556^{*}}$ \\
\hline NR & $\underline{0.704}$ & 1 & NR I & $\underline{0.667}$ & 1 & $0.304 *$ & $0.096^{*}$ \\
\hline & & & NR II & $\underline{0.709}$ & $\underline{0.709}$ & 1 & $0.424^{*}$ \\
\hline & & & NR III & $\underline{0.716}$ & $\underline{0.589}$ & $\underline{0.736}$ & 1 \\
\hline
\end{tabular}

Wherein = Czekanowski: upper diagonal (*); Sørensen: lower diagonal. Underlined values were considered similar. 
flowering plants (angiosperms), formed by an opulent and cosmopolitan group of plants (APG III 2009). Among the other ruling families in richness, Myrtaceae (six), Erythroxylaceae (five), Annonaceae (five), Bignoniaceae (five), Vochysiaceae (five) and Rubiaceae (four) can also be listed.

Magonia pubescens, a particular kind of Cerrado species (Eiten 1983), was dominant for both strata (almost 5,750 individuals ha- ${ }^{-1}$, being 557 individuals ha- ${ }^{-1}$ in adult and 5,187 individuals ha ${ }^{-1}$ in natural regeneration). Santos and Vieira (2005) highlighted the adaptive ability of this species in areas of stricto sensu Cerrado in Três Marias, MG, Brazil. Bridgewater et al. (2004) found this species among the 100 most frequent in the central-southeastern phytogeographical province (Ratter et al. 2003). According to Ratter et al. (2003), this species and Terminalia argentea are classified as soil fertility indicators.

Values of Shannon diversity (H') and Pielou evenness (J') suggest that the diversity pattern between strata has similar complexity. It is known that extractivist activities are carried out in this area; however, it is impossible to analyze directly such degree of interference in the vegetation. Such fact leads into two reverse interpretations: either the plant community remains free of significant anthropogenic interferences within its composition and structure, or the opposite, current diversity does not accurately reflect human action, being quite tolerant to such interactions.

Furthermore, vegetation resistance as a community can be noticed, especially above-mentioned populations regarded as dominant (adult and natural regeneration), stand out Magonia pubescens, Aspidosperma tomentosum, Vatairea macrocarpa, Kielmeyera coriacea, Astronium fraxinifolium and Piptocarpha rotundifolia species and the genera Byrsonima, Pouteria, Qualea and Erythroxylum. Yet regarding Casearia sylvestris, which was introduced among the four most frequent in natural regeneration, two hypotheses may be stated: either the species is in early colonization process, or environmental and/or anthropogenic factors prevent the full establishment of the plant in this area.

The analysis of the beta diversity indicates the degree of substitution of species along a gradient (Primack and Rodrigues 2001), even in the temporal dimension (MacArthur and Wilson 1967).

Comparing adult and natural regeneration, a low beta temporal diversity in terms of richness was observed, which was better expressed by Sørensen index. Medeiros et al. (2007) also found high similarity (low beta diversity) between both strata by means of Sørensen qualitative index and concluded community dynamic equilibrium, with possible changes on floristic composition, mainly in the rank of the main species. Thus, by the current overview given by this study, there is evidence that floristic composition will remain in its successional course. Contrarily, making use of quantitative index, the overall temporal beta diversity analysis is high and indicates that floristic structure of the adult stratum tends to change by the potential for recruiting new taxa from natural regeneration. However after a detailed analysis of the natural regeneration size classes (I, II and III), the potential to recruit new species decreases with increasing sizes of the individuals.

Qualitatively, natural regeneration classes are similar between themselves and they resemble adult stratum. For the comparison of adult and natural regeneration classes, by Czekanowski index, a reduction on dissimilarity is observed, though culminating in values of adult stratum similar to the later classes of diameter (II and III). Indicating that as more individuals grow in size, approaching the adult values, the beta diversity (quantitative) tends to decrease, and there are higher chances of maintaining community structure. The qualitative temporal beta diversity seems to not change the extent that the natural regeneration approaches the class adult, becoming nearer from one another.

Considering structural aspects and excluding exclusive species of natural regeneration (potential immigrants), this result shows the plant species colonization strategy. Polyembryony has been demonstrated in Cerrado species, as found for Magonia pubescens (Salomão and Allem 2001); it helps to justify the high density of natural regeneration compared with adult stratum, structurally. Adding that survival curves inherent in most plant populations (J-inverted or Type III: high mortality as seedling with a negative exponential trend - firstly proposed by Pearl in 1928) explain the increasing similarity between adult and natural regeneration classes since, under natural selection pressure, the actual populations of natural regeneration tends to decrease and resemble adult structure in a process led primarily by environmental conditions (Bray and Curtis 1957).

There is an expected result for the last natural regeneration diameter class, in which similarity between adult and natural regeneration class III is observed. Structurally, more similarities to adult stratum were expected, on account of the larger sizes. Sørensen, which is even more sensitive to species richness changes, detected similarity in this pairwise comparison.

The species that might have undergone such disturbances are Bowdichia virgilioides, Plathymenia reticulata, Annona crassiflora, Handroanthus ochraceus and Machaerium opacum since specimens in natural regeneration class III were not found; though they are representative in density in the other classes of natural regeneration and in the adult stratum.

Is worth noting that there are species that have contributed to the qualitative and quantitative dissimilarity, due to their small growth habit, of which we can stand out Bauhinia rufa and Peritassa campestris, whose inclusion criteria for admission in adult stratum has restricted the occurrence of these taxa. Moreover, Brosimum gaudichaudii, Duguetia forfuracea, Rourea induta, Senna macranthera, Erythroxylum campestris, Erythroxylum daphnites and others may also be included into this list, once these species, even after an advanced maturity level, are commonly found in lower layers or undergrowth forest. 


\section{CONCLUSIONS}

Floristic composition between adults and natural regeneration is qualitatively similar, nevertheless with peculiarities that can result in increase in alpha diversity of adult stratum due to recruitment of new species from natural regeneration. The quantitative beta temporal diversity is high between the strata, but there is a trend of increasing similarities with the growth of natural regeneration plants. It can be said that the plant community has self-regeneration features for most populations, with slight changes in its structure. Which suggests that these species probably will be part of the future of this community. The hypothesis of the alfa diversity being superior and natural regeneration resembling the adult stratum, i.e. low beta diversity, was confirmed by this study.

Information for understanding the community structure and composition are partially distributed among the studied strata; therefore, being complementary. From data of the comparison between the structures natural regeneration and adult, it is possible to infer about the stability of the community, as well as to understand the processes of replacement of the species and structural changes along a gradient of ages in an area and, thus, support projects for the recovery and management of these areas.

\section{REFERENCES}

APG III (Angiosperm Phylogeny Group, US). 2009. An update of the Angiosperm Phylogeny Group classification for the orders and families of flowering plants: APG III. Botanical Journal of the Linnean Society 161: 105-121.

Barreira S, JRS Scolforo, SA Botelho, JM Mello. 2002. Estudo da estrutura da regeneração natural e da vegetação adulta em um Cerrado sensu stricto para fins de manejo florestal. Scientia Florestalis 61: 64-78.

Bray RJ, JT Curtis. 1957. An ordination of the upland forest communities of southern Wisconsin. Ecological Monographs 27: 325-349.

Bridgewater S, JA Ratter, JF Ribeiro. 2004. Biogeographic patterns, b-diversity and dominance in the Cerrado biome of Brazil. Biodiversity and Conservation 13: 2295-2318.

Eiten G. 1983. Fitossociologia de um hectare de Cerrado. Brasil Florestal 54: 55-70.

Felfili JM, FA Carvalho, RF Haidat. 2005. Manual para o monitoramento de parcelas permanentes nos biomas Cerrado e Pantanal. Brasilia, Brasil. UnB. 55 p.

Felfili JM, MC Silva-Júnior, AC Sevilha, CW FAGG, BMT Walter, PE Nogueira, AV Rezende. 2004. Diversity, floristic and structural patterns of Cerrado vegetation in central Brazil. Plant Ecology 175: 37-46.

Felfili JM, MC Silva-Júnior. 2001. Biogeografia do Bioma Cerrado. Estudo fitofisionômico na Chapada do espigão Mestre do São Francisco. Brasilia, Brasil. UnB. 152 p.

Felfili JM, MC Silva-Júnior. 2005. Diversidade alfa e beta no Cerrado sensu stricto, Distrito Federal, Goiás, Minas Gerais e Bahia. In Scariot A, JC Souza-Silva, JM Felfili eds. Cerrado: ecologia, biodiversidade e conservação. Brasília,
Brasil. Ministério do Meio Ambiente. p. 141-154.

Finol UH. 1971. Nuevos parámetros a considerarse en el análisis estructural de las selvas vírgenes tropicales. Revista Forestal Venezuelana 14(21): 29-42.

Guariguata MR, R Ostertag. 2001. Neotropical secondary forest succession: changes in structural and functional characteristics. Forest Ecology and Management 148: 185-206.

Guariguata MR, RL Chazdon, JS Denslow, JM Dupuy, L Anderson. 1997. Structure and floristics of secondary and oldgrowth forest stands in lowland Costa Rica. Plant Ecology 132: 107-120.

Kent M, P Coker. 1992. Vegetation description and analysis, a practical approach. London, UK. Belhaven Press. 215 p.

Legendre P, L Legendre. 1998. Numerical ecology. 2nd ed. Amsterdam, The Netherlands. Elsevier Science. 853 p.

Libano AM, JM Felfili. 2006. Mudanças temporais na composição florística e na diversidade de um Cerrado sensu stricto do Brasil Central em um período de 18 anos (1985-2003). São Paulo. Acta Botanica Brasilica 20(4): 927-936.

MacArthur RH, EO Wilson. 1967. The theory of island biogeography. Princeton, New Jersey, USA. Princeton University. 203 p.

Medeiros MM, JM Felfini, ML Andréia. 2007. Compactação florístico-estrutural dos estratos de regeneração e adulto em Cerrado sensu stricto no Brasil Central. Revista Cerne 13: 291-298.

Mendonça RC, JM Felfili, BMT Walter, MC da Silva-Júnior, AV Rezende, TS Filgueiras, PE Nogueira, CW Fagg. 2008. Flora vascular do bioma Cerrado: checklist com 12.356 espécies. In Sano SM, SP Almeida eds. Cerrado: ecologia e flora. Planaltina. Embrapa Cerrados 2: 289-556.

Missouri Botanical Garden. 2014. Tropicos. Accessed May. 2014. Available at http://www.tropicos.org

Mittermeier RA, GAB Fonseca, AB Rylands, K Brandon. 2005. A brief history of biodiversity conservation in Brazil. Conservation Biology 19(3): 601-611.

Mueller-Dombois D, H Ellenberg. 1974. Aims and methods of vegetation ecology. New York, USA. John Wiley. 547 p.

Palmer MW. 1990. The estimation of species richness by extrapolation. Ecology 71: 1195-1198.

Palmer MW. 1991. Estimating species richness: the second-order jackknife estimator reconsidered. Ecology 72: 1512-1513.

Pearl R. 1928. The Rate of Living. New York, USA. Knopf. 185 p.

Primack RB, E Rodrigues. 2001. Biologia da Conservação. Londrina, Brasil. Editora Planta. 327 p.

Ratter JA, S Bridgewater, JF Ribeiro. 2003. Analysis of the floristic composition of the Brazilian Cerrado vegetation. III: comparison of the woody vegetation of 376 areas. Edinburgh Journal of Botany 60: 57-109.

Ribeiro JF, BMT Walter. 2008. As principais Fitofisionomias do Bioma Cerrado. In Sano S, SP Almeida, JF Ribeiro eds. Cerrado: ecologia e flora. Brasilia, Brasil. EMBRAPA. p. 152-212.

Salomão AN, AC Allen. 2001. Polyembryony in angiospermous trees of the brazilian Cerrado and caatinga vegetation. Acta Botanica Brasilica 15: 369-378.

Santos RM, FA Vieira. 2005. Comparação do componente arbóreo entre três áreas de Cerrado em diferentes estádios de conservação no município de Três Marias, Minas Gerais, Brasil. Lavras. Revista Cerne 11(4): 399-408.

Scolforo JR, JM Mello, AD Oliveira (eds.). 2008. Inventário flo- 
restal de Minas Gerais: Cerrado-florística, estrutura, diversidade, similariadade, distribuição diamétrica e de altura, volumetria, tendências de crescimento e áreas aptas para manejo florestal. Lavras, Brasil. Universidade Federal de
Lavras. 135 p.

Strahler A, AN Strahler. 2002. Physical geography: science and systems of the human environment. $2^{\text {nd }}$. ed. New York, USA. John Wiley. 748 p.

Recibido: 10.08 .15

Aceptado: 12.07.16 